\title{
Indigenous Yeast, Lactic Acid Bacteria, and Acetic Acid Bacteria from Cocoa Bean Fermentation in Indonesia Can Inhibit Fungal-Growth-Producing Mycotoxins
}

\author{
Endang Sutriswati Rahayu ${ }^{1,2, *}$, Rokhmat Triyadi ${ }^{3}$, Rosyida N. B. Khusna ${ }^{1}$, Titiek Farianti Djaafar ${ }^{4, *}$, \\ Tyas Utami ${ }^{1}$, Tri Marwati ${ }^{4}$ and Retno Utami Hatmi ${ }^{4}$ \\ 1 Department of Food and Agricultural Product Technology, Universitas Gadjah Mada, \\ Yogyakarta 55281, Indonesia; rosyidanbk@mail.ugm.ac.id (R.N.B.K.); tyas_utami@ugm.ac.id (T.U.) \\ 2 Centre for Food and Nutrition Studies, Universitas Gadjah Mada, Yogyakarta 55281, Indonesia \\ 3 Provincial Office of Drug and Food Control, Bali 80234, Indonesia; pomdenpasar@yahoo.co.id \\ 4 Department of Postharvest, Assessment Institute for Agricultural Technology, Yogyakarta 55584, Indonesia; \\ watipasca2@gmail.com (T.M.); bptpyogya@yahoo.com (R.U.H.) \\ * Correspondence: endangsrahayu@ugm.ac.id (E.S.R.); titiekfd1212@gmail.com (T.F.D.); \\ Tel.: +62-812-2792-5997 (T.F.D.)
}

check for updates

Citation: Rahayu, E.S.; Triyadi, R.; Khusna, R.N.B.; Djaafar, T.F.; Utami, T.; Marwati, T.; Hatmi, R.U. Indigenous Yeast, Lactic Acid Bacteria, and Acetic Acid Bacteria from Cocoa Bean Fermentation in Indonesia Can Inhibit Fungal-Growth-Producing Mycotoxins. Fermentation 2021, 7, 192. https://doi.org/10.3390/ fermentation7030192

Academic Editors: Amparo Gamero and Mónica Gandía

Received: 24 August 2021

Accepted: 10 September 2021

Published: 14 September 2021

Publisher's Note: MDPI stays neutral with regard to jurisdictional claims in published maps and institutional affiliations.

Copyright: (c) 2021 by the authors. Licensee MDPI, Basel, Switzerland. This article is an open access article distributed under the terms and conditions of the Creative Commons Attribution (CC BY) license (https:/ / creativecommons.org/licenses/by/ $4.0 /)$.

\begin{abstract}
Cocoa bean fermentation is an important process in the manufacturing of cocoa products It involves microbes, such as lactic acid bacteria, yeast, and acetic acid bacteria. The presence of mold in cocoa bean fermentation is undesired, as it reduces the quality and may produce mycotoxins, which can cause poisoning and death. Aspergillus niger is a fungus that produces ochratoxin A, which is often found in dried agricultural products such as seeds and cereals. In this study, we applied indigenous Candida famata HY-37, Lactobacillus plantarum HL-15, and Acetobacter spp. HA37 as starter cultures for cocoa bean fermentation. We found that the use of L. plantarum HL-15 individually or in combination Candida famata HY-37, Lactobacillus plantarum HL-15, and Acetobacter spp. HA-37 as a starter for cocoa bean fermentation can inhibit the growth of A. niger YAC-9 and the synthesis of ochratoxin A during fermentation and drying. With biological methods that use indigenous Lactobacillus plantarum HL-15 individually or in combination with Candida famata HY-37 and Acetobacter spp. HA-37, we successfully inhibited contamination by ochratoxin-A-producing fungi. Thus, the three indigenous microbes should be used in cocoa bean fermentation to inhibit the growth of fungi that produce mycotoxins and thus improve the quality.
\end{abstract}

Keywords: Candida famata HY-37; Lactobacillus plantarum HL-15; Acetobacter spp. HA-37; cocoa bean fermentation; anti-fungal growth; ochratoxin A

\section{Introduction}

Quality fermented cocoa (Theobroma cacao Linn.) beans are the main raw materials in the processing of chocolate. The cocoa bean fermentation process plays an important role in the production of quality cocoa beans for various chocolate products and other products made from cocoa beans. During cocoa bean fermentation, the mucilaginous pulp is removed, thus preventing germination and initiating the development of the aroma, flavor, and color [1-4].

Successful fermentation of cocoa beans is determined by three microbes, namely yeast, lactic acid bacteria (LAB), and acetic acid bacteria (AAB), which grow naturally. Under the anaerobic conditions of the first $24 \mathrm{~h}$ of fermentation, yeast is dominant. Then, the fermentation continues, and the pulp is drained such that air can enter the mass of the cocoa beans. In these conditions, LAB and AAB grow well after about $24-72 \mathrm{~h}$ of fermentation $[2,5,6]$.

In unfavorable fermentation conditions, fungi are found, causing negative effects on the quality and safety cocoa beans [7-9]. Certain fungal species can produce mycotoxins, such as ochratoxin A [10-12]. Several studies have been conducted in an attempt to reduce 
contamination by mycotoxin-producing fungi. The detoxification methods conducted are chemical, physical [13-15], and biological methods [16-18]. The use of biological methods with antagonistic microbes is considered safer than the use of chemical and physical methods. Lactic acid bacteria are a type of bacteria that can be used in biological methods to prevent contamination with ochratoxin A by inhibiting fungal growth and ochratoxin A synthesis [8].

The presence of bacteria that produce lactic acid (LAB) in the fermentation of cocoa beans has potential inhibitory properties against mycotoxin-producing fungi $[8,19,20]$. Yeast also has potential as an antifungal agent because it produces proteinaceous metabolites [8]. Therefore, it is necessary to conduct research that aims to find isolates of the indigenous LAB of fermented cocoa beans that have potential as antifungal agents against fungi that produce mycotoxins. Indigenous lactic acid bacteria were isolated from the fermentation of cocoa beans in the Gunungkidul district, Yogyakarta [21]. The LAB identified as Lactobacillus plantarum HL-15 has antifungal activity against A. niger YAC-9. At the same time, the authors of [22] also isolated yeast and acetic acid bacteria from fermented cocoa beans in the Gunungkidul Regency, Yogyakarta. Thus, in this study, we report that the abilities of indigenous Candida famata HY-37, L. plantarum HL-15, and Acetobacter spp. HA-37 to inhibit fungal growth that results in the production of ochratoxin A. With biological methods that use the indigenous LAB individually or in combination with yeast and $A A B$, we have successfully inhibited contamination with ochratoxin-A-producing fungi.

\section{Materials and Methods}

\subsection{Media and Equipment}

The media used were Standard Plate Count Agar (APHA) (OXOID CM0463 Basingstoke, England), Dichloran Rose Bengal Chloramphenicol Agar (DRBC) (MERCK Darmstadt, Germany), de Man Ragosa Sharpe broth (MRSB) (MERCK Darmstadt, Germany), Bacteriological Peptone (OXOID LP0037 Basingstoke, England), D (+)-glucose (MERCK Darmstadt, Germany), yeast extract (OXOID LP0021 Basingstoke, England) and malt extract broth (MEB) (MERCK Darmstadt, Germany), bacteriological Agar (OXOID LP0011 Basingstoke, England), calcium carbonate $\left(\mathrm{CaCO}_{3}\right)(\mathrm{MERCK}$ Darmstadt, Germany), 0.85\% $\mathrm{NaCl}$ solution, $3 \% \mathrm{H}_{2} \mathrm{O}_{2}$ solution, $0.32 \% \mathrm{CaCO}_{3}$ solution, $20 \%$ glycerol solution, and skim milk. The equipment used included luminaire flow, petri dishes, 0.1 and $1 \mathrm{~mL} \mathrm{mi-}$ cropipettes, conical tube, Erlenmeyer flask, Quebec colony counter, stomacher, vortex, shaker, incubator, microscope, ELISA test kit (AgraQuant@ELISA Ochratoxin Assay 2/40) (ROMER Labs, Singapore, Singapore), and spectrophotometer.

\subsection{Sample and Microorganisms}

Cocoa fruits of the Lindak variety were obtained from the Sido Dadi farmer group (Gunungkidul Regency, Yogyakarta) for the fermentation assessment. The indigenous L. plantarum HL-15 LAB, Candida famata HY-37 yeast, Acetobacter spp. HA-37 AAB are microbes that were isolated from cocoa bean fermentation in previous research $[21,22]$ and were maintained in the Center for Food and Nutrition Studies (FNCC), Universitas Gadjah Mada, Yogyakarta. The A. niger YAC-9 fungus was used as an ochratoxin A producer [23] and was obtained from the FNCC.

\subsection{Preparation of Microorganisms for Cocoa Bean Fermentation}

The media for C. famata HY-37 were malt extract broth $(20 \mathrm{~g} / \mathrm{L})$; MRS broth $(52 \mathrm{~g} / \mathrm{L})$ was used for L. plantarum HL-15; peptone $(4,5 \mathrm{~g} / \mathrm{L})$, glucose $(20 \mathrm{~g} / \mathrm{L})$, and yeast extract (4,5 g/L) were used for Acetobacter spp. HA-37. Culture rejuvenation was performed by taking 1-2 of the cultures, placing them into the growing media, and then incubating at $37^{\circ} \mathrm{C}$ for $24 \mathrm{~h}$. Furthermore, $5 \mathrm{~mL}$ of the cultures were transferred to an Erlenmeyer flask containing $50 \mathrm{~mL}$ of each growing medium and incubated at $37^{\circ} \mathrm{C}$ for $24 \mathrm{~h}$. The culture 
starter was stored in a cool room until it was used. The concentration of the starter cultures used for cocoa bean fermentation was $10^{9} \mathrm{CFU} / \mathrm{mL}$.

The A. niger YAC-9 culture was grown in an MEA slant tube at $25^{\circ} \mathrm{C}$ for 7 days. Spores were harvested using $0.1 \%$ Tween 80 ; thus, the final concentration was $10^{9} \mathrm{CFU} / \mathrm{mL}$ [9].

\subsection{Fermentation of Cocoa Beans}

Cocoa bean fermentation was performed with the following four treatments: (1) natural fermentation; (2) fermentation through the addition of L. plantarum HL-15 and A. niger YAC-9; (3) natural fermentation through the addition of A. niger YAC-9; (4) fermentation through the addition of mixed starter cultures of L. plantarum HL-15, C. famata HY-37, Acetobacter spp. HA-37, and A. niger YAC-9.

A total of $2.5 \mathrm{~kg}$ of cocoa beans were placed into a bamboo basket, and with the starter culture was added according to the treatment. As much as $25 \mathrm{~mL}$ of the starter culture was added, with a total culture of $10^{9} \mathrm{CFU} / \mathrm{mL}$. The top of the bamboo basket was covered with banana leaves and burlap sacks. Then, the fermentation of cocoa beans was conducted at room temperature for 5 days and reserved for two days. After fermentation, the cocoa beans were immersed for $1 \mathrm{~h}$ and then washed. Furthermore, the fermented cocoa beans were sun dried in a greenhouse. The drying was conducted for 5 days until the water content of the cocoa beans reached $7-8 \%$.

The analysis was performed every day during the fermentation and drying; it included an analysis of the $\mathrm{pH}$, temperature, and total microbial count of the $\mathrm{LAB}, \mathrm{AAB}$, yeast, and A. niger YAC-9. Total microbial count analysis was conducted by using the pour-plate method [24]. The analysis of $\mathrm{pH}$ was conducted by using $\mathrm{pH}$ meter [6].

\subsection{Extraction and Analysis of Ochratoxin A}

The analysis of ochratoxin A was conducted based on the method from [12] with modifications during the fermentation and drying. The sampling for the ochratoxin $\mathrm{A}$ analysis was conducted during the fermentation and drying (days $0,1,5$, and 10). Twenty-gram samples were blended, transferred into $250 \mathrm{~mL}$ Erlenmeyer flask, added with $100 \mathrm{~mL}$ methanol: demineralized water $(7: 3, v / v)$, and then shaken for $3 \mathrm{~min}$. The solution was filtered using by Whatman filter paper number 1 . A total of $2 \mathrm{~mL}$ of filtrate was taken and stored in an Eppendorf vial. The ochratoxin A produced by A. niger YAC-9 was measured with a solidphase direct enzyme immunoassay using ELISA test kit, the AgraQuant ${ }^{\circledR}$ ELISA Ochratoxin Assay 2/40, which is designed for cocoa products (ROMER Labs, Singapore, Singapore).

\subsection{Statistical Analysis}

All experiments were conducted in triplicate, and the results are reported as mean \pm standard deviation $(\mathrm{SD}, \mathrm{n}=3)$.

\section{Results}

\subsection{Cocoa Bean Fermentation}

The microbial growth patterns and changes in the $\mathrm{pH}$ and temperature of all treatments for cocoa bean fermentation can be seen in Figures 1-4. At the beginning of fermentation, the growth of the yeast increased, followed by the growth of lactic acid bacteria, and these began to decline on day 2 until the end of fermentation (day 5). 


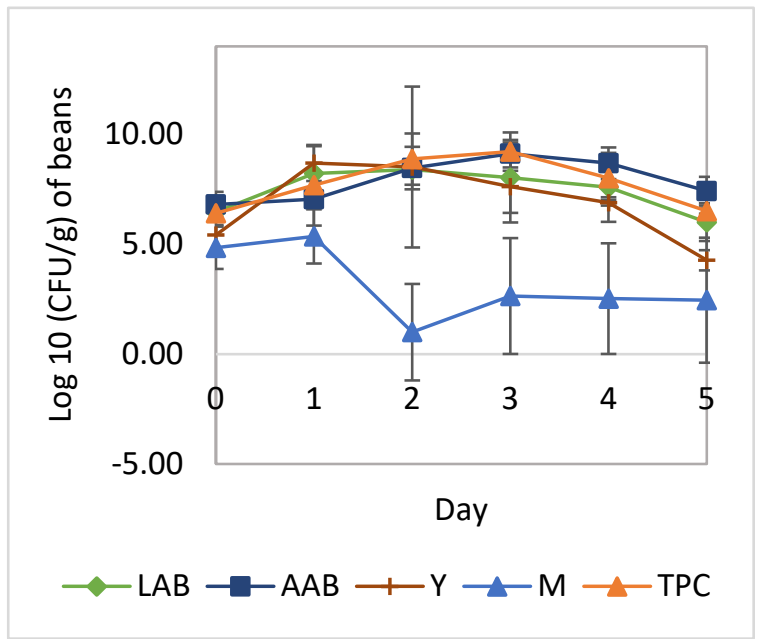

(a)

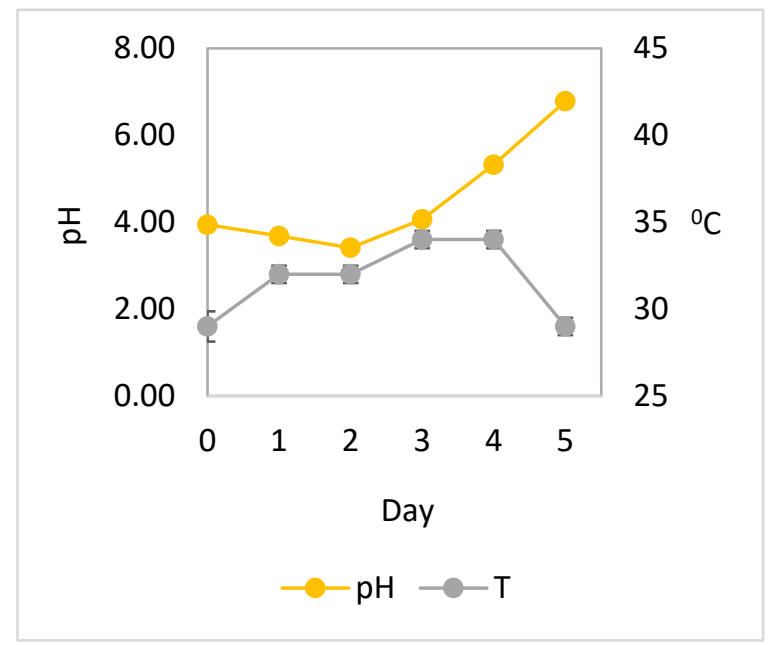

(b)

Figure 1. Microbial growth patterns and changes in $\mathrm{pH}$ and temperature during the natural fermentation of cocoa beans: (a) growth of yeast, $\mathrm{LAB}, \mathrm{AAB}$, and mold; (b) temperature and $\mathrm{pH}$. LAB, total lactic acid bacteria; $\mathrm{AAB}$, total acetic acid bacteria; $\mathrm{Y}$, total yeast; $\mathrm{M}$, total mold; TPC, total plate count; $\mathrm{pH}, \mathrm{pH}$ pulp; $\mathrm{T}$, temperature.

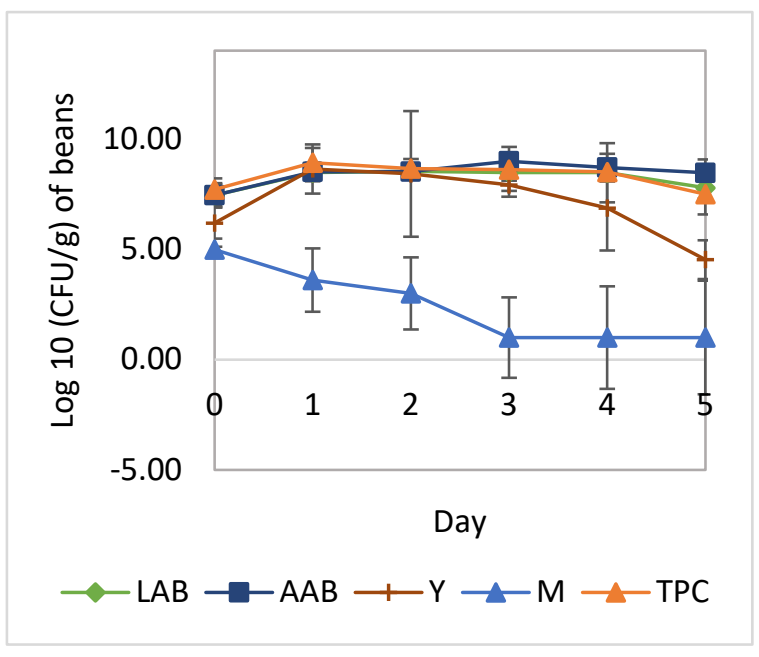

(a)

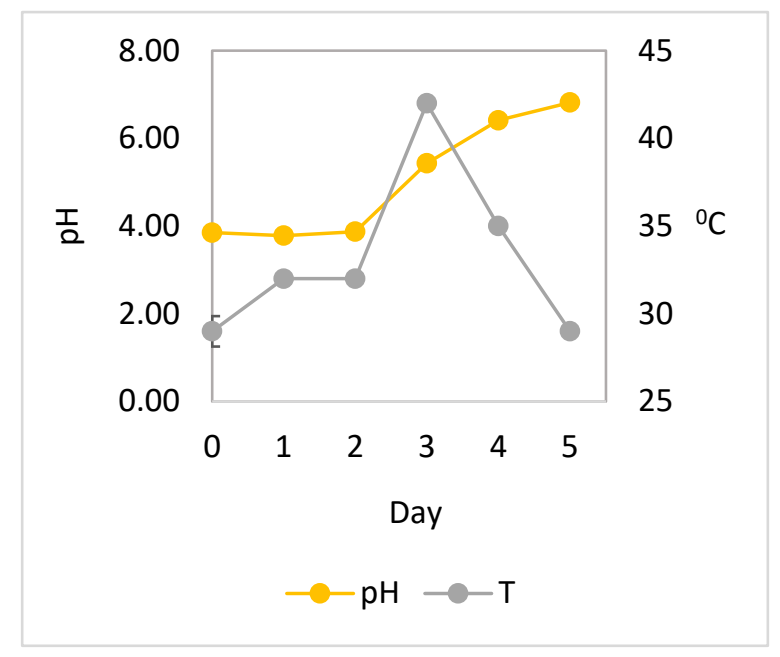

(b)

Figure 2. Microbial growth patterns and changes in $\mathrm{pH}$ and temperature during cocoa bean fermentation with the addition of L. plantarum HL-15 and A. niger YAC-9: (a) growth of yeast, LAB, AAB, and mold during fermentation; (b) temperature and $\mathrm{pH}$. LAB, total lactic acid bacteria; $\mathrm{AAB}$, total acetic acid bacteria; $\mathrm{Y}$, total yeast; $\mathrm{M}$, total mold; TPC, total plate count; $\mathrm{pH}, \mathrm{pH}$ pulp; $\mathrm{T}$, temperature. 


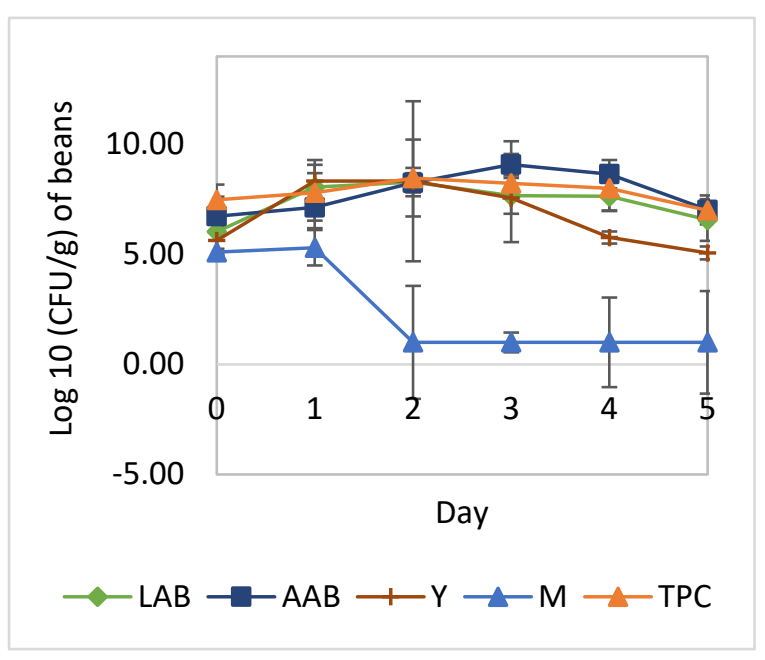

(a)

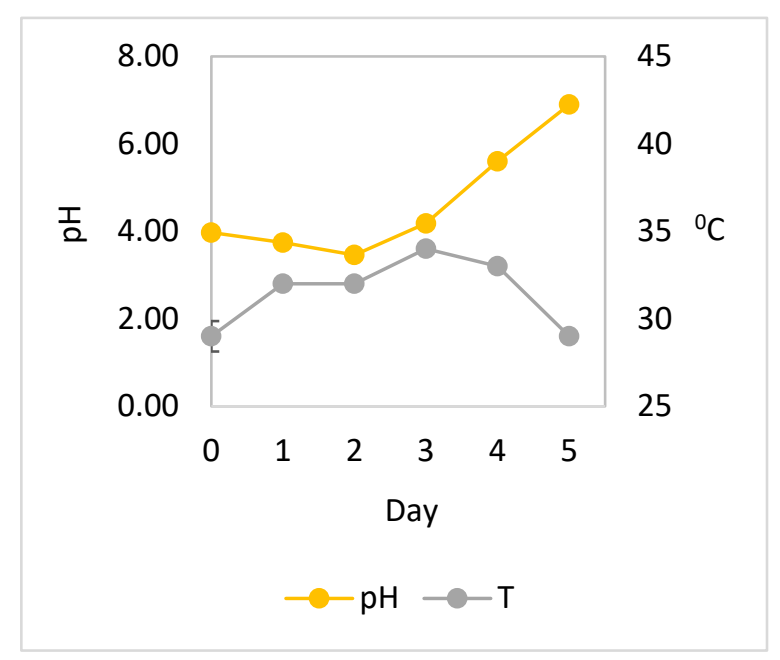

(b)

Figure 3. Microbial growth patterns and changes in $\mathrm{pH}$ and temperature during the natural fermentation of cocoa beans with the addition of $A$. niger YAC-9: (a) growth of yeast, LAB, AAB, and mold; (b) temperature and pH. LAB, total lactic acid bacteria; $\mathrm{AAB}$, total acetic acid bacteria; $\mathrm{Y}$, total yeast; $\mathrm{M}$, total mold; TPC, total plate count; $\mathrm{pH}, \mathrm{pH}$ pulp; $\mathrm{T}$, temperature.

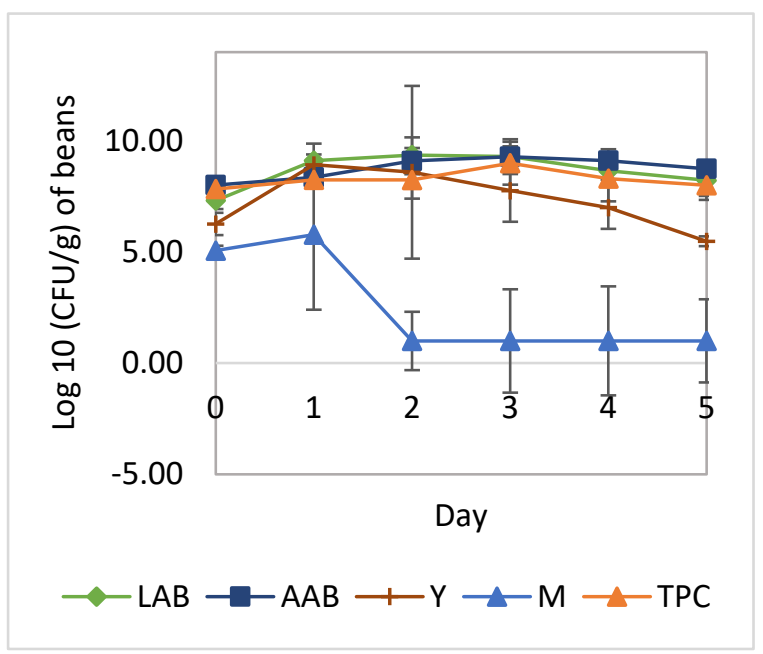

(a)

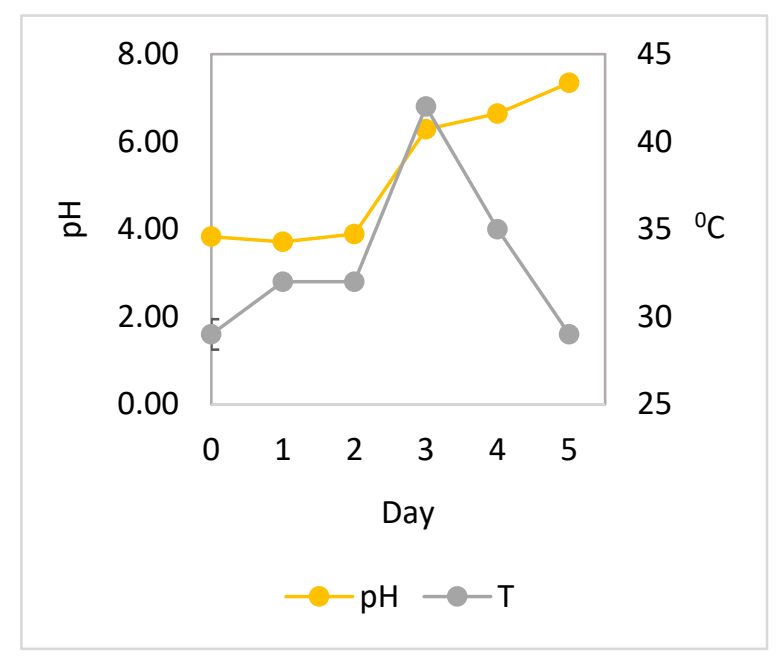

(b)

Figure 4. Microbial growth patterns and changes in $\mathrm{pH}$ and temperature during the fermentation of cocoa beans with the addition of L. plantarum HL-15, C. famata HY-37, Acetobacter spp. HA-37, and A. niger YAC-9: (a) growth of yeast, LAB, AAB, and mold; (b) temperature and $\mathrm{pH}$. LAB, total lactic acid bacteria; $\mathrm{AAB}$, total acetic acid bacteria; $\mathrm{Y}$, total yeast; $\mathrm{M}$, total mold; TPC, total plate count; $\mathrm{pH}, \mathrm{pH}$ pulp; $\mathrm{T}$, temperature.

The cocoa bean fermentation with the addition of L. plantarum HL-15 as a starter culture individually or in combination with C. famata HY-37 and Acetobacter spp. HA-37 was able to inhibit the growth of A. niger YAC-9 (Figures 2 and 4). A. niger YAC-9, which was added to the spontaneous cocoa bean fermentation process, was also able to inhibit growth (Figure 3). The growth of $A$. niger YAC-9 could be inhibited by as much as 1 log. This shows that in spontaneous fermentation, there is the growth of yeast, $\mathrm{BAL}$, and $\mathrm{AAB}$, which causes the temperature in the fermentation box to increase such that the fungus does not grow.

The addition of LAB individually or in a mixed culture with yeast and acetic acid bacteria (Figures 2 and 4 ) resulted in a greater increase in temperature compared to fermen- 
tation without the addition of all three cultures-L. plantarum HL-15, C. famata HY-37, and Acetobacter spp. HA-37 (Figures 1 and 3).

\subsection{Drying of Fermented Cocoa Beans}

The growth patterns of $C$. famata HY-37, L. plantarum HL-15, Acetobacter spp. HA-37, and A. niger YAC-9 can be seen in Figure 5. The use of L. plantarum HL-15 as a starter culture was able to inhibit mold growth during fermentation and drying. The population of A. niger YAC-9 increased on drying days 8 and 9, but at the end of the drying, it decreased by about 4 logs for the cocoa beans fermentation with L. plantarum HL-15 or in combination with C. famata HY-37 and Acetobacter spp. HA-37 (Figure 5b,d). During the cocoa bean fermentation without the addition of C. famata HY-37, L. plantarum HL-15, and Acetobacter spp. HA-37 (Figure $5 \mathrm{a}, \mathrm{c}$ ), the A. niger YAC-9 population continued to increase until the end of drying (day 10).

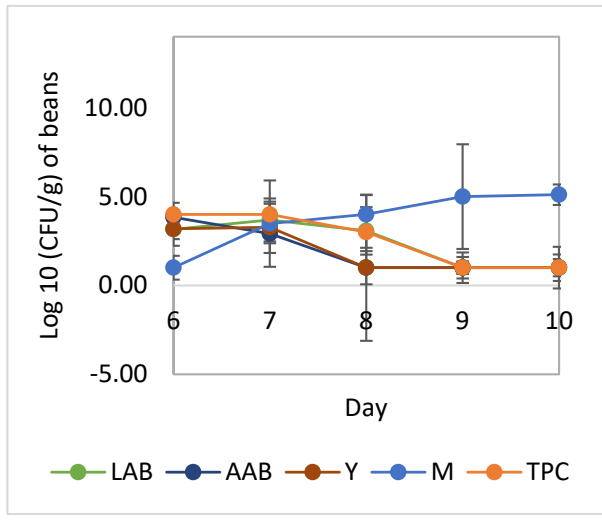

(a)

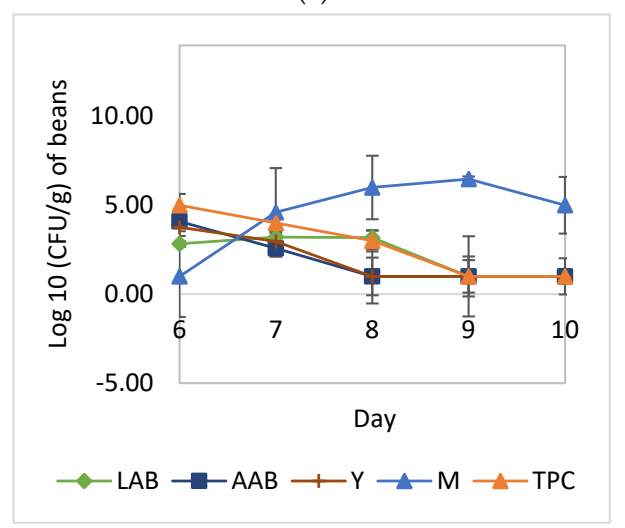

(c)

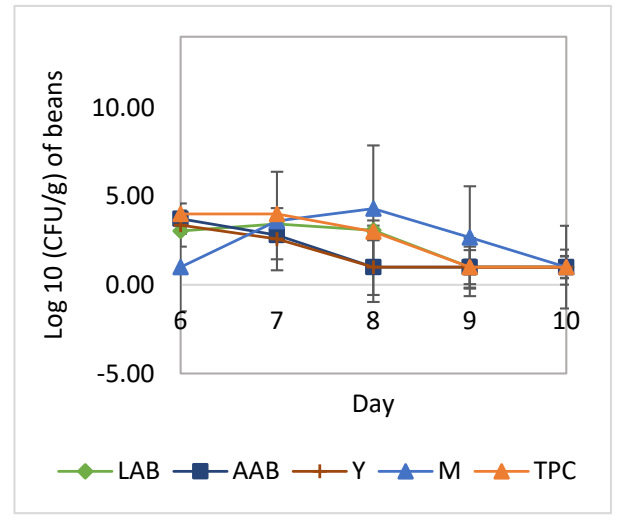

(b)

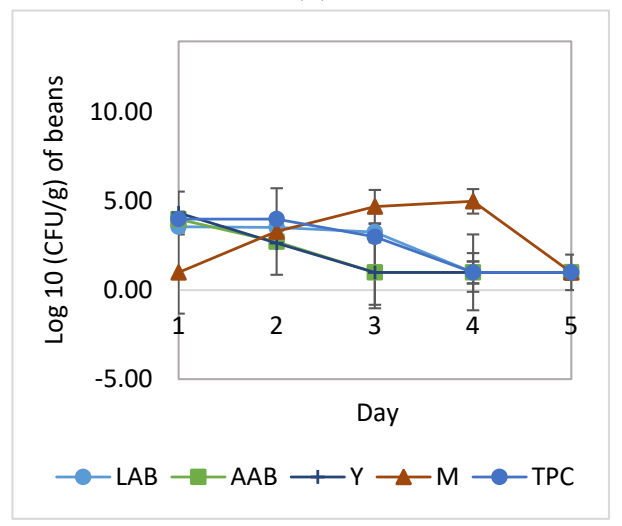

(d)

Figure 5. Growth of yeast, $\mathrm{LAB}, \mathrm{AAB}$, and mold during the course of drying: (a) natural fermentation; (b) fermentation with the addition of L. plantarum HL-15 and A. niger YAC-9; (c) natural fermentation with the addition of $A$. niger YAC-9; (d) fermentation with the addition of L. plantarum HL-15, C. famata HY-37, Acetobacter spp. HA-37, and Aspergillus niger YAC-9. LAB, total lactic acid bacteria; AAB, total acetic acid bacteria; $\mathrm{Y}$, total yeast; $\mathrm{M}$, total mold; TPC, total plate count.

\subsection{Ochratoxin A Level in Fermented Cocoa Beans}

The concentration of ochratoxin A (OTA) during fermentation and drying is presented in Figure 6. During fermentation, the synthesis of OTA occurred, but with the addition of a culture starter, the synthesis of OTA may be inhibited (Figure 6b,d). This is consistent with the inhibition of the growth of $A$. niger YAC-9 through the addition of L. plantarum HL-15 individually or in combination with C. famata HY-37 and Acetobacter spp. HA-37 (Figures 2a and $4 a$ ). Similarly, during the drying process, the OTA synthesis was inhibited by the presence of L. plantarum HL-15. 


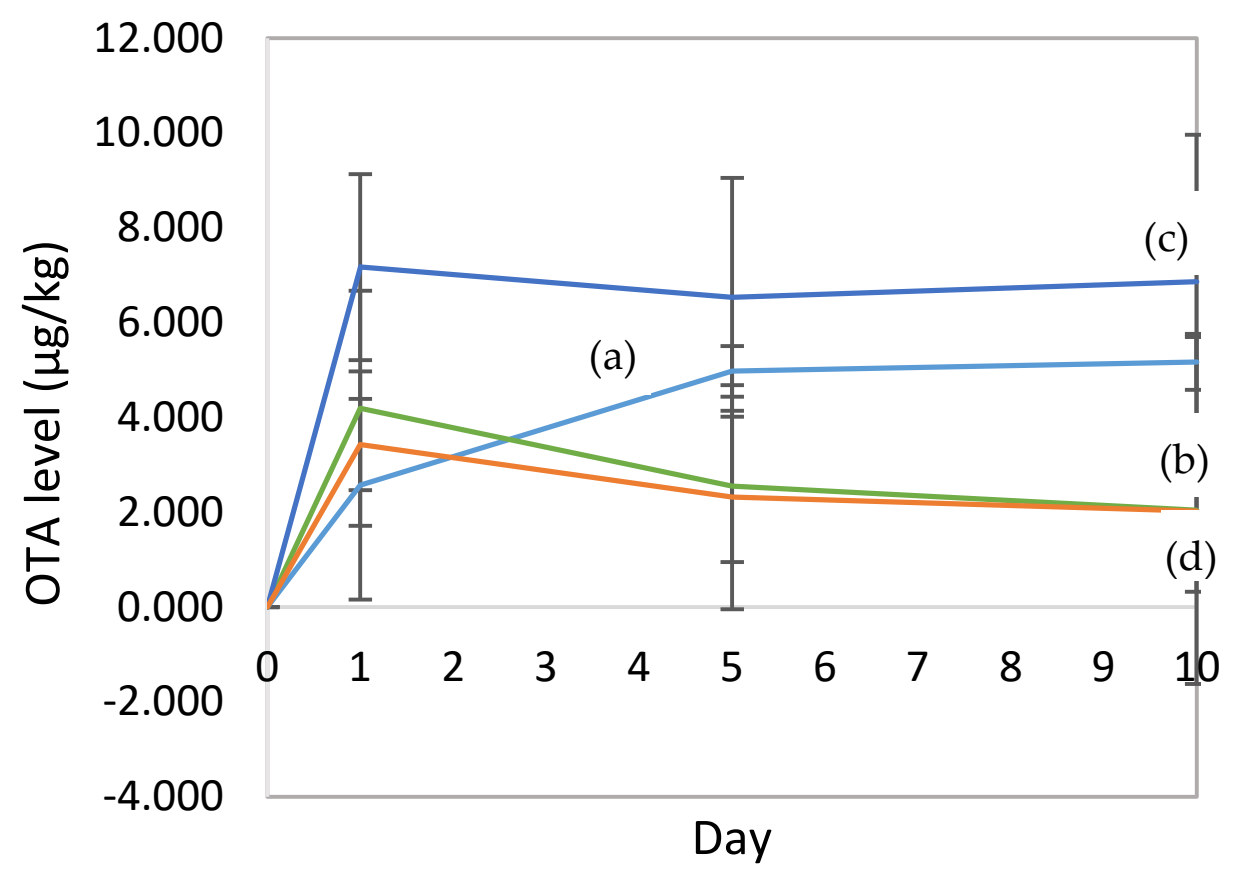

Figure 6. The OTA concentration during fermentation (days 0, 1, and 5) and drying (day 10): (a) natural fermentation; (b) fermentation of cocoa beans with the addition of L. plantarum HL-15 and A. niger YAC-9 as a contaminant; (c) fermentation of cocoa beans with the addition of $A$. niger YAC-9 as a contaminant; (d) cocoa bean fermentation with the addition of a mixed starter culture consisting of L. plantarum HL-15, C. famata HY-37, Acetobacter spp. HA-37, and A. niger YAC-9 as a contaminant. $(\mathbf{b}, \mathbf{d})$ show lower levels of ochratoxin contamination than those of $(\mathbf{a}, \mathbf{d})$. This shows that there was a good effect from the addition of the LAB.

The OTA content during the fermentation with the addition of A. niger YAC-9 as a contaminant had a different pattern (Figure 6c); the OTA content on the first day of fermentation reached $7.17 \mu \mathrm{g} / \mathrm{kg}$. This yield was considerably greater than that of the cocoa beans in the other treatments.

In this study, the initial $\mathrm{pH}$ of the cocoa pulp was about 4.0. On day 2 of fermentation, the $\mathrm{pH}$ decreased due to the formation of organic acids due to the microbial metabolism; along with the decrease in $\mathrm{pH}$, there was a decrease in the OTA concentration (Figure 6).

The external appearance of the dry cocoa beans in this treatment showed fungal contamination due to the appearance of fungal mycelia adhering to the surface of the beans and the discoloration of the beans (Figure 7c). No OTA was detected in the cocoa pulp before fermentation. The ochratoxin A was formed consistent with the growth of $A$. niger YAC-9, as seen in Figures 1-5. 


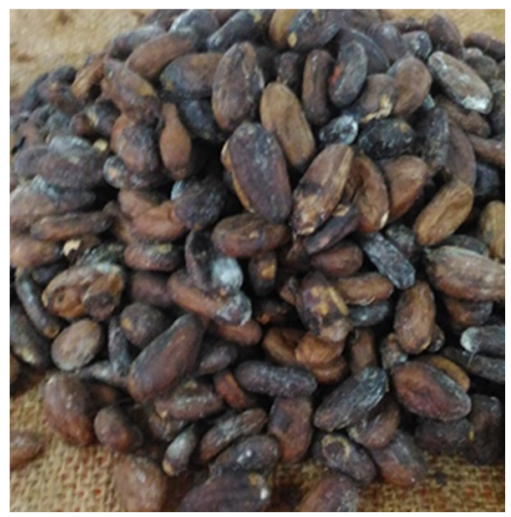

(a)

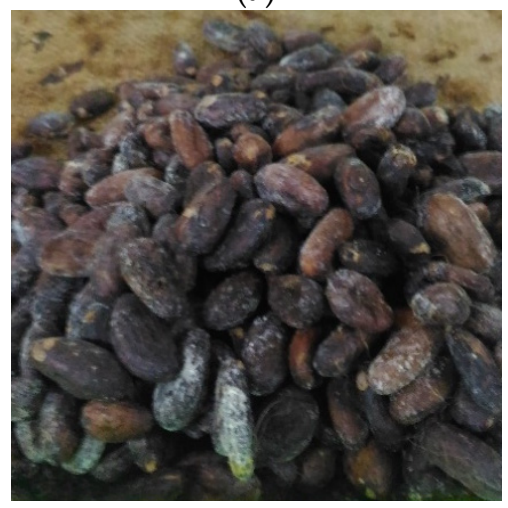

(c)

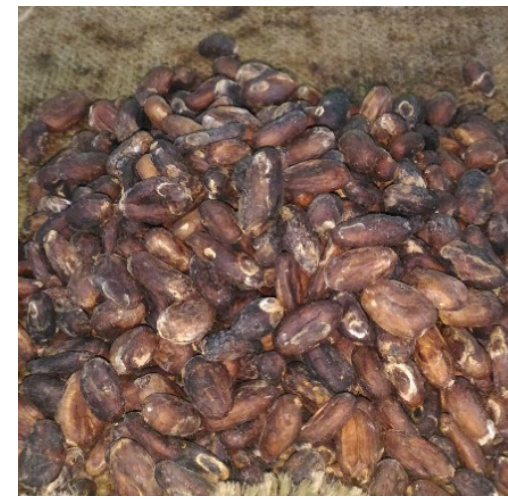

(b)

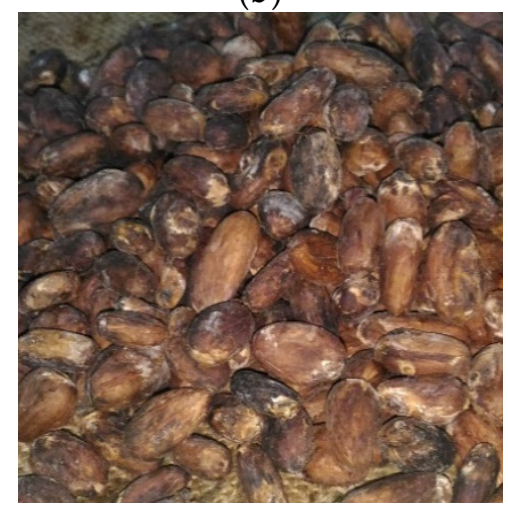

(d)

Figure 7. The appearance of fungal mycelia on the surfaces of the dry cocoa beans (days 10): (a) natural fermentation; (b) fermentation of cocoa beans with the addition of L. plantarum HL-15 and A. niger YAC-9; (c) cocoa bean fermentation with the addition of A. niger YAC-9; (d) cocoa bean fermentation with the addition of a mixed starter consisting of L. plantarum HL-15, C. famata HY-37, Acetobacter spp. HA-37, and A. niger YAC-9. There were no fungal mycelia in the treatments in (b,d). The color of the fermented cocoa beans that were contaminated by A. niger was blackish brown, as shown in $(\mathbf{a}, \mathbf{c})$.

\section{Discussion}

Cocoa bean fermentation plays an important role in the production of quality cocoa beans. The three main microbes involved in the fermentation of cocoa beans are yeast, LAB, and $\mathrm{AAB}[2,5,25-27]$. Fungal contamination is the main problem in the fermentation of cocoa beans by cocoa farmers. Fungal contamination produces toxins that cause fermented cocoa beans to be unsafe when used as a raw material for the chocolate processing industry. In addition, it causes fermented cocoa beans to have a low quality, especially if there are fungal mycelia on the surfaces of the cocoa beans. Therefore, we conducted cocoa bean fermentation with the addition of yeast, $\mathrm{LAB}$, and $\mathrm{AAB}$, which are known to have antifungal properties. The LAB had the ability to inhibit the growth of fungi throughout the fermentation and drying of the cocoa beans $[6,20,28]$.

The growth patterns of yeast, $\mathrm{LAB}$, and $\mathrm{AAB}$ in this study are in accordance with what has been conveyed in previous studies. At the beginning of fermentation, yeast growth increased, followed by the growth of lactic acid bacteria; these began to decline from day 2 until the end of fermentation (day 5). However, the growth of AAB increased after two days of fermentation and decreased from the fourth to the fifth day. This is consistent with the results of research conducted by other authors [4,5]. At the beginning of fermentation, a depectinization reaction occurred due to the yeast; thus, the viscosity of the pulp decreased, allowing air to enter the mass of the cocoa beans [25]. Aeration encourages the growth of $\mathrm{AAB}$ and suppresses the growth of yeast [4]. Lactic acid bacteria metabolize 
glucose to produce lactic acid, alcohols, acetic acid, glycerol, mannitol, and $\mathrm{CO}_{2}$. Acetic acid bacteria oxidize alcohol to produce acetic acid; then, acetic acid is oxidized to produce $\mathrm{CO}_{2}$ and water come out through the basket $[2,6]$.

Temperature and $\mathrm{pH}$ changes occurred during cocoa bean fermentation. The initial temperature of fermentation was $29^{\circ} \mathrm{C}$. The increases in temperature were different in each treatment, ranging from 34 to $42^{\circ} \mathrm{C}$ within $48-60 \mathrm{~h}$. Then, there was a gradual decrease in temperature to $29^{\circ} \mathrm{C}$ at the end of fermentation. The authors of [25] stated that the increase in the temperature of fermented cocoa beans from the ambient temperature $\left(25-30^{\circ} \mathrm{C}\right)$ to $35-40{ }^{\circ} \mathrm{C}$ within $48 \mathrm{~h}$ is due to the production of ethanol in an exothermic process. Research conducted by Ouattara et al. [29] also showed that the temperature was $29^{\circ} \mathrm{C}$ at the beginning of the fermentation and reached a peak of $45{ }^{\circ} \mathrm{C}$ for $48-72 \mathrm{~h}$ with the addition of lactic acid bacteria. The $\mathrm{pH}$ value in the fermenting cocoa mass was in the range of 3.8-4.0 in the initial stage of fermentation (0-48 h). After $48 \mathrm{~h}$, the $\mathrm{pH}$ increased to 4.5-7.5 until the end of fermentation.

The growth of the yeast, $\mathrm{LAB}$, and $\mathrm{AAB}$ during the drying of the fermented cocoa beans decreased until the last day of drying. This growth agrees with the findings of research conducted by other authors [30]. This is because the drying process reduces the moisture content in the beans; thus, it is difficult for the microbes to grow.

The OTA content in the natural cocoa bean fermentation increased during the fermentation to a level of $4.97 \mu \mathrm{g} / \mathrm{kg}$, although the sizes of the fungal populations decreased. This is because the OTA levels in cocoa beans accumulate and do not decrease during fermentation, although the sizes of the fungal populations decrease. The concentrations of mycotoxins in cocoa beans are retained in their shells [30]. There was an increase in the OTA levels during the drying of the naturally fermented cocoa beans to a level of $5.17 \mu \mathrm{g} / \mathrm{kg}$ at the end of drying. The increase in OTA levels was consistent with the increase in the sizes of the mold populations during drying (5.11 Log CFU/g on day 10).

The high OTA levels were related to the amount of A. niger YAC-9 added to the sample as a contaminant. The OTA level decreased slightly at the end of fermentation but increased at the end of the drying. This is consistent with the growth patterns of the fungi in this treatment. The fungi decreased in population until the end of fermentation, but when drying, the population of fungi continued to increase. The addition of the A. niger YAC-9 starter increased the size of the fungal population and the OTA levels in the cocoa beans. A. niger YAC-9 is known to be able to produce $57.68 \mathrm{ppb}$ of OTA [23].

The use of the indigenous L. plantarum HL-15 as a starter culture individually or in combination with C. famata HY-37 and Acetobacter spp. HA-37 contributed to the reduction of the A. niger YAC-9 population and the OTA concentration in fermented cocoa beans. The results of our study prove that the use of yeast, $\mathrm{LAB}$, and $\mathrm{AAB}$ cultures in the fermentation of cocoa beans can inhibit the growth of mycotoxin-producing fungi. Thus, the cocoa beans produced will be of a high quality and will have a high level of safety. The ability of LAB to bind with mycotoxins or reduce mycotoxin levels was also found in other studies $[6,8,16]$. Ngang et al. [28] found that the addition of an LAB isolate of A19 (Pediococcus damnosus) as a starter in cocoa fermentation with OTA-producing molds (Aspergillus niger and Aspergillus carbonarius) could inhibit the growth of the molds until they were almost undetectable, and the toxin production was reduced by $99 \%$. Blagojev et al. [31] mentioned several possible mechanisms or interactions between lactic acid bacteria and mycotoxins, such as the inhibition of mycotoxin biosynthesis, the binding of mycotoxins to bacterial cell walls, or the detoxification of mycotoxins. The accumulation OTA in fermented cocoa beans can also be suppressed through the formation of organic acids during fermentation [32]. Aspergillus niger contamination and the synthesis of OTA during the fermentation of cocoa beans can be inhibited by using C. famata HY-37, L. plantarum HL-15, and Acetobacter spp. HA-37 as a starter culture such that the cocoa beans produced are of a good quality and are safe. 


\section{Conclusions}

We found that the use of indigenous L. plantarum HL-15 either individually or in combination with C. famata HY-37 and Acetobacter spp. HA-37 as a culture starter in the fermentation process of cocoa beans can inhibit the growth of $A$. niger YAC-9 and OTA synthesis. Based on this, it is recommended that LAB, especially L. plantarum HL-15, be used in the fermentation of cocoa beans to improve the quality. This research must be continued in order to elucidate the roles of the three indigenous microbes in determining the quality of the flavor of fermented cocoa beans.

\section{Patents}

a. Patent: Dry Starter Manufacturing Process of L. plantarum HLM-15 for MycotoxinProducing Fungus Control, 2017 (IDS000001851) (in Indonesian)

b. Patent Cocoa Bean Fermentation Process with the Addition of Starter L. plantarum HL-15 to Inhibit Fungal Growth, 2019 (IDS000002554) (in Indonesian)

Author Contributions: E.S.R., T.F.D., T.M., and T.U. carried out the conceptualization and developed the methodology; R.T. and R.N.B.K. performed the experiments and analyzed the data. E.S.R., T.F.D., T.M., and T.U. wrote and reviewed the original manuscript; T.F.D., T.M., and R.U.H. wrote and edited the manuscript. All authors have read and agreed to the published version of the manuscript.

Funding: This research was funded by the Indonesian Agricultural Research and Development Agency (IAARD) with the contract numbers 54.19/H.M.240/I.1/03/2016.K (7th March 2016) and 55/60/HM.240/H.1/03/2017.K (20th March 2017).

Institutional Review Board Statement: Not applicable.

Informed Consent Statement: Not applicable.

Data Availability Statement: The data presented in this study are available on request from the corresponding author.

Acknowledgments: The authors thank the Indonesian Agricutural Agency Research Development (IAARD) for their support through the Project with contract number 54.19 /HM.240/I.1/3/2016.K, 2016, and 55.60/HM.240/H.1/03/2017.K, 2017. Thanks also goes to Sikstus Gusli for providing writing assistance.

Conflicts of Interest: The authors declare no conflict of interest.

\section{References}

1. Bortolini, C.; Patrone, V.; Puglisi, E.; Morelli, L. Detailed analyses of the bacterial populations in processed cocoa beans of different geographic origin, subject to varied fermentation conditions. Int. J. Food Microbiol. 2016, 236, 98-106. [CrossRef]

2. Hamdouche, Y.; Meile, J.C.; Lebrun, M.; Guehi, T.; Boulanger, R.; Teyssier, C.; Montet, D. Impact of turning, pod storage and fermentation time on microbial ecology and volatile composition of cocoa beans. Food Res. Int. 2019, 119, 477-491. [CrossRef]

3. Ramos, S.; Salazar, M.; Nascimento, L.; Carazzolle, M.; Pereira, G.; Delforno, T.; Nascimento, M.; de Aleluia, T.; Celeghini, R.; Efraim, P. Influence of pulp on the microbial diversity during cupuassu fermentation. Int. J. Food Microbiol. 2020, $318,108465$. [CrossRef]

4. Lima, C.O.; Vaz, A.B.M.; De Castro, G.M.; Lobo, F.; Solar, R.; Rodrigues, C.; Martins Pinto, L.R.; Vandenberghe, L.; Pereira, G.; Miúra da Costa, A.; et al. Integrating microbial metagenomics and physicochemical parameters and a new perspective on starter culture for fine cocoa fermentation. Food Microbiol. 2021, 93, 103608. [CrossRef]

5. Miguel, M.G.; da Castro, L.V.; Efraim, P.; Santos, C.; Lima, N.; Schwan, R.F. Cocoa fermentation: Microbial identification by MALDI-TOF MS, and sensory evaluation of produced chocolate. LWT Food Sci. Technol. 2017, 77, 362-369. [CrossRef]

6. Ho, V.T.T.; Fleet, G.H.; Zhao, J. Unravelling the contribution of lactic acid bacteria and acetic acid bacteria to cocoa fermentation using inoculated organisms. Int. J. Food Microbiol. 2018, 279, 43-56. [CrossRef] [PubMed]

7. Taniwaki, M.H.; Pitt, J.I.; Magan, N. Aspergillus species and mycotoxins: Occurrence and importance in major food commodities. Curr. Opin. Food Sci. 2018, 23, 38-43. [CrossRef]

8. Ruggirello, M.; Nucera, D.; Cannoni, M.; Peraino, A.; Rosso, F.; Fontana, M.; Cocolin, L.; Dolci, P. Antifungal activity of yeasts and lactic acid bacteria isolated from cocoa bean fermentations. Food Res. Int. 2019, 115, 519-525. [CrossRef] [PubMed]

9. Akinfala, T.O.; Houbraken, J.; Sulyok, M.; Adedeji, A.R.; Odebode, A.C.; Krska, R.; Ezekiel, C.N. Moulds and their secondary metabolites associated with the fermentation and storage of two cocoa bean hybrids in Nigeria. Int. J. Food Microbiol. 2020, 316, 108490. [CrossRef] [PubMed] 
10. Cabañes, F.J.; Bragulat, M.R. Black aspergilli and ochratoxin A-producing species in foods. Curr. Opin. Food Sci. 2018, 23, 1-10. [CrossRef]

11. Alves da Silva, S.; Fonseca Alvarenga Pereira, R.G.; de Azevedo Lira, N.; Micotti da Glória, E.; Chalfoun, S.M.; Batista, L.R. Fungi associated to beans infested with coffee berry borer and the risk of ochratoxin A. Food Control. 2020, 113, 107204. [CrossRef]

12. Da Silva, A.R.P.; Fungaro, M.H.P.; Silva, J.J.; Martins, L.M.; Taniwaki, M.H.; Iamanaka, B.T. Ochratoxin A and related fungi in Brazilian black pepper (Piper nigrum L.). Food Res. Int. 2021, 142, 110207. [CrossRef] [PubMed]

13. Karlovsky, P.; Suman, M.; Berthiller, F.; De Meester, J.; Eisenbrand, G.; Perrin, I.; Oswald, I.P.; Speijers, G.; Chiodini, A.; Recker, T.; et al. Impact of food processing and detoxification treatments on mycotoxin contamination. Mycotoxin Res. 2016, 32, 179-205. [CrossRef] [PubMed]

14. Makhuvele, R.; Naidu, K.; Gbashi, S.; Thipe, V.C.; Adebo, O.A.; Njobeh, P.B. The use of plant extracts and their phytochemicals for control of toxigenic fungi and mycotoxins. Heliyon 2020, 6, e05291. [CrossRef]

15. Mousavi Khaneghah, A.; Hashemi Moosavi, M.; Oliveira, C.A.F.; Vanin, F.; Sant'Ana, A.S. Electron beam irradiation to reduce the mycotoxin and microbial contaminations of cereal-based products: An overview. Food Chem. Toxicol. 2020, 143, 111557. [CrossRef]

16. Shehata, M.G.; Badr, A.N.; El Sohaimy, S.A.; Asker, D.; Awad, T.S. Characterization of antifungal metabolites produced by novel lactic acid bacterium and their potential application as food biopreservatives. Ann. Agric. Sci. 2019, 64, 71-78. [CrossRef]

17. Gavahian, M.; Mathad, G.N.; Oliveira, C.A.F.; Mousavi Khaneghah, A. Combinations of emerging technologies with fermentation: Interaction effects for detoxification of mycotoxins? Food Res. Int. 2021, 141, 110104. [CrossRef] [PubMed]

18. Du, G.; Liu, L.; Guo, Q.; Cui, Y.; Chen, H.; Yuan, Y.; Wang, Z.; Gao, Z.; Sheng, Q.; Yue, T. Microbial community diversity associated with Tibetan kefir grains and its detoxification of Ochratoxin A during fermentation. Food Microbiol. 2021, 99, 103803. [CrossRef]

19. Romanens, E.; Freimüller Leischtfeld, S.; Volland, A.; Stevens, M.; Krähenmann, U.; Isele, D.; Fischer, B.; Meile, L.; Miescher Schwenninger, S. Screening of lactic acid bacteria and yeast strains to select adapted anti-fungal co-cultures for cocoa bean fermentation. Int. J. Food Microbiol. 2019, 290, 262-272. [CrossRef] [PubMed]

20. Sadiq, F.A.; Yan, B.; Tian, F.; Zhao, J.; Zhang, H.; Chen, W. Lactic Acid Bacteria as Antifungal and Anti-Mycotoxigenic Agents: A Comprehensive Review. Compr. Rev. Food Sci. Food Saf. 2019, 18, 1403-1436. [CrossRef]

21. Marwati, T.; Khusna, R.N.B.; Djaafar, T.F.; Rahayu, E.S. Inhibition Growth of Mycotoxin Producing Fungi by Lactic Acid Bacteria Isolated from Fermented Cocoa Bean (Theobroma cacao L.) in Indonesia. In Proceedings of the 15th ASEAN Conference on Food Science and Technology, Ho Chi Minh City, Vietnam, 14-17 November 2017; Volume 2, pp. 295-302.

22. Djaafar, T.F.; Marwati, T.; Rahayu, E.S. Isolation and Identification of Yeast and Acetic Acid Bacteria from Cocoa Bean (Theobroma cacao Linn.) Fermentation in Gunung Kidul Regency, Yogyakarta, Indonesia Titiek. In Proceedings of the 15th ASEAN Conference on Food Science and Technology, Ho Chi Minh City, Vietnam, 14-17 November 2017; Volume 1, pp. $189-194$.

23. Nugroho, A.D.; Setyabudi, F.M.C.S.; Salleh, B.; Rahayu, E.S. Ochratoxingenic Black Aspergilli Isolated from Dried Agricultural Products in Yogyakarta, Indonesia. J. Food Sci. Biotechnol. 2013, 3, 472-480.

24. da Silva Duarte, V.; Carlot, M.; Pakroo, S.; Tarrah, A.; Lombardi, A.; Santiago, H.; Corich, V.; Giacomini, A. Comparative evaluation of cheese whey microbial composition from four Italian cheese factories by viable counts and 16S rRNA gene amplicon sequencing. Int. Dairy J. 2020, 104, 104656. [CrossRef]

25. De Vuyst, L.; Weckx, S. The cocoa bean fermentation process: From ecosystem analysis to starter culture development. J. Appl. Microbiol. 2016, 121, 5-17. [CrossRef] [PubMed]

26. Fossi, B.; Ngah, B.; Nchanji, G.; Wanji, S.; Ndjouenkeu, R. Lactobacilli Cultures against Ochratoxin A Producing Moulds Isolated from Cocoa in the South West Region of Cameroon. Br. Microbiol. Res. J. 2016, 15, 1-16. [CrossRef]

27. Santos, D.S.; Rezende, R.P.; Dos Santos, T.F.; Marques, E.D.; Ferreira, A.C.; e Silva, A.B.; Romano, C.C.; da Cruz Santos, D.W.; Dias, J.C.; Bisneto, J.D. Fermentation in fine cocoa type Scavina: Change in standard quality as the effect of use of starters yeast in fermentation. Food Chem. 2020, 328, 7-12. [CrossRef]

28. Essia Ngang, J.J.; Yadang, G.; Sado Kamdem, S.L.; Kouebou, C.P.; Youte Fanche, S.A.; Tsochi Kougan, D.L.; Tsoungui, A.; Etoa, F.X. Antifungal properties of selected lactic acid bacteria and application in the biological control of ochratoxin A producing fungi during cocoa fermentation. Biocontrol Sci. Technol. 2015, 25, 245-259. [CrossRef]

29. Ouattara, D.H.; Ouattara, H.G.; Goualie, B.G.; Kouame, L.M.; Niamke, S.L. Biochemical and functional properties of lactic acid bacteria isolated from Ivorian cocoa fermenting beans. J. Appl. Biosci. 2014, 77, 6489. [CrossRef]

30. Schwan, R.F.; Wheals, A.E. The microbiology of cocoa fermentation and its role in chocolate quality. Crit. Rev. Food Sci. Nutr. 2004, 44, 205-221. [CrossRef] [PubMed]

31. Blagojev, N.; Škrinjar, M.; Vesković-Moračanin, S.; Šošo, V. Control of mould growth and mycotoxin production by lactic acid bacteria metabolites. Rom. Biotechnol. Lett. 2012, 17, 7219-7226.

32. Copetti, M.V.; Iamanaka, B.T.; Mororó, R.C.; Pereira, J.L.; Frisvad, J.C.; Taniwaki, M.H. The effect of cocoa fermentation and weak organic acids on growth and ochratoxin A production by Aspergillus species. Int. J. Food Microbiol. 2012, 155, 158-164. [CrossRef] 